\title{
Kinetic Study of Adsorption of Poly (acrylic acid) and Sodium Dodecyl Sulfate on Alumina Particles
}

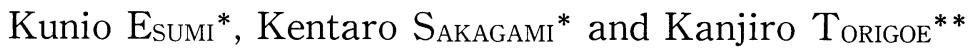

\begin{abstract}
The adsorption kinetics of poly (acrylic acid) (PAA) and sodium dodecyl sulfate (SDS) on alumina particles at pH 5.2 was investigated by measuring the amount of PAA and SDS adsorbed and the dispersion stability of suspensions with time. The adsorption of single systems of PAA and SDS showed a similar behavior that the adsorption increases rapidly and then saturates. In the simultaneous adsorption of PAA and SDS at two initial concentrations of SDS which correspond to the formation of a monolayer and a bilayer of SDS, respectively, the adsorption of PAA increased markedly at an early stage, decreased, and then became constant, while the adsorption of SDS exhibited a similar behavior to that of SDS alone. In addition, the dispersion stability of alumina suspensions with time was also affected by adsorption of PAA/SDS. The mechanism of adsorption kinetics of PAA and SDS on alumina particles was discussed.
\end{abstract}

\section{Key-words : Adsorption kinetics of polymer and surfactant ; Alumina; Dispersion stability}

\section{Introduction}

Adsorption of polymers and surfactants from their mixed solutions onto solid particles has been studied to understand interfacial interactions at solid/liquid interfaces ${ }^{1)}$. Depending on the surface properties of solids as well as the aqueous properties of polymers and surfactants, the adsorption behavior can be classified as follows. A competitive adsorption occurs when the interactions between polymers and surfactants in aqueous solutions are weak. If the interactions are strong and the polymer or surfactant has a strong affinity with the solid surface, enhancement of the adsorption of the other may occur. The former case includes poly (ethylene oxide)-cationic surfactant-silica ${ }^{2)}$, while as the latter case a simultaneous adsorption of poly (vinylpyrrolidone) (PVP) and anionic surfactants-alumina ${ }^{3)}$, silica ${ }^{4)}$, or -titanium dioxide ${ }^{5)}$ has been reported. In

Received April 16, 2001

* Department of Applied Chemistry and Institute of Colloid and Interface Science, Science University of Tokyo, Kagurazaka, Shinjuku-ku, Tokyo 162-8601, Japan

** Department of Industrial Chemistry, Faculty of Engineering, Science University of Tokyo, Kagurazaka, Shinjuku-ku, Tokyo 162-8601, Japan addition, the conformation change in the polymer adsorption by addition of surfactants has been characterized by ESR. For example, in the simultaneous adsorption of PVP and anionic surfactants on alumina ${ }^{3)}$, the conformation of adsorbed PVP becomes flattened with an increase of the anionic surfactant concentration. Furthermore, a good correlation between the conformation of adsorbed PVP and the thickness of the PVP layer for PVP-anionic surfactants-polystyrene latex has been obtained ${ }^{6}$. The information obtained has often helped us to understand the mechanisms of dispersion and flocculation of solid particles. Most studies for simultaneous adsorption of polymers and surfactants so far have been discussed from the standpoint of adsorption equilibrium, although adsorption kinetics of polymers and surfactants is also important.

Recently, several techniques including reflectometry $^{7-12)}$ have been employed to elucidate adsorption kinetics of polymers or surfactants where solids are limited to flat substrates. During the adsorption process, it is important to study the interaction of particles caused by adsorption of polymers and surfactants. Such particle interactions can control the dispersion stability of particles. Accordingly it is necessary to employ solid particles for that purpose. We have 
studied $^{13)}$ the adsorption kinetics of PVP and sodium dodecyl sulfate (SDS) on alumina particles by measuring the amount adsorbed and the dispersion stability of solid suspensions with time and found that the adsorption behavior of PVP with time is significantly affected by the initial SDS concentration and the dispersion stability of the suspensions is changed due to the adsorption of SDS-PVP with time. In the PVP-SDS-alumina system, PVP alone hardly adsorbs on the alumina surface, while SDS alone appreciably adsorbs.

The objective of this study is to investigate the kinetics of simultaneous adsorption of poly(acrylic acid) (PAA) and SDS onto alumina particles, where both PAA and SDS adsorb on alumina. The dispersion stability of alumina suspensions by adsorption of PAA and SDS is also kinetically elucidated.

\section{Experimental Section}

Materials. PAA $(\mathrm{Mw}=50,000)$ was obtained from Tokyo Kasei Kogyo and used as received. SDS was commercially obtained and recrystallized several times from ethanol. As a substrate, $\alpha$-alumina supplied by Showa Denkou K. K. was used: the average particle diameter and specific surface area were $2.51 \mu \mathrm{m}$ and $8.9 \mathrm{~m}^{2} \mathrm{~g}^{-1}$, respectively. Water used in this study was deionized through a Milli-Q Plus system. The other chemicals were of reagent grade.

Methods and Measurements. A mixed aqueous solution of PAA and SDS $(200 \mathrm{ml})$ was added into alumina particles $(5 \mathrm{~g})$ and then the suspension was stirred at $25^{\circ} \mathrm{C}$. During stirring, samples taken $(1 \mathrm{ml})$ at each interval were filtered with syringe filter. The separation time for the filtration was about $10 \mathrm{~s}$. The $\mathrm{pH}$ of suspensions adjusted with $\mathrm{HCl}$ was about 5.2. The concentrations of PAA solutions were determined by a colloidal titration using analytical poly(diallyldimethylammonium chloride) solutions, while those of SDS solution were determined using an HPLC method. The amounts of PAA and SDS adsorbed were calculated from the difference between the initial and final solution concentrations. To obtain adsorption isotherms of SDS alone and of PAA-SDS mixed systems on alumina particles, the suspensions containing alumina, SDS, or PAA-SDS were stirred at $25^{\circ} \mathrm{C}$ for $24 \mathrm{~h}$.

Another adsorption experiment was carried out. As is the first procedure, an aqueous solution of SDS (4 or 10 mmol $\left.\mathrm{dm}^{-3}\right)$ or PAA $\left(0.8 \mathrm{~g} \mathrm{dm}^{-3}\right)$ was added to alumina particles and the suspension was stirred for $1 \mathrm{~h}$. An aqueous solution of PAA or SDS was then introduced into the suspension.

The dynamic dispersion stability of alumina particles in SDS, PAA, or PAA-SDS solutions was evaluated using a Turbiscan-on-line (Formulaction, France). Five hundred milliliters of PAA and SDS aqueous solution was added to $5.0 \mathrm{~g}$ of alumina in a beaker. The suspension was passed continuously through the optical sensor of the Turbiscan which can detect transmission and backscattering information. The intensity of backscattering light depends on the mean path length of photon in the dispersion; the percent of backscattered light increases with decreasing mean particle diameter.

All of the measurements except for the HPLC measurements were carried out at $25^{\circ} \mathrm{C}$.

\section{Results and Discussion}

Before discussing the kinetics of adsorption of PAA and SDS on alumina, it is important to study the interaction of PAA and SDS on alumina at equilibrium condition. Figure 1 shows the adsorption isotherms of PAA and SDS on alumina at pH 5.2. Since the zeta potential of alumina particles at this $\mathrm{pH}$ is positive, it is expected that a strong interaction between an anionic surfactant and positively charged alumina particles occurs. At high SDS concentrations where the occupied area of SDS is calculated as about $0.2 \mathrm{~nm}^{2}$, a SDS bilayer is formed by the hydrophobic interaction between the first and second layer of SDS on alumina. On the other hand, the adsorption of PAA increased with an increase of PAA concentration and then reached a plateau. The main driving forces for PAA adsorption are probably due to electrostatic attraction force between negatively charged carboxyl groups of PAA and positively charged alumina sites as well as hydrogen bonding between PAA and hydroxyl groups of alumina ${ }^{14)}$. In addition, a result of simultaneous adsorption of PAA and SDS is shown in Fig. 2, where

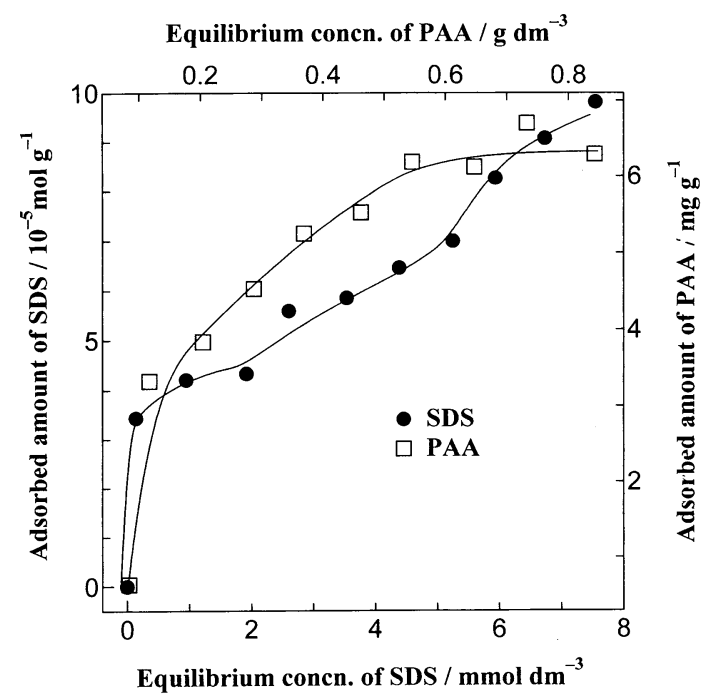

Fig. 1 Adsorption isotherms of PAA and SDS on alumina at $25^{\circ} \mathrm{C}$. 


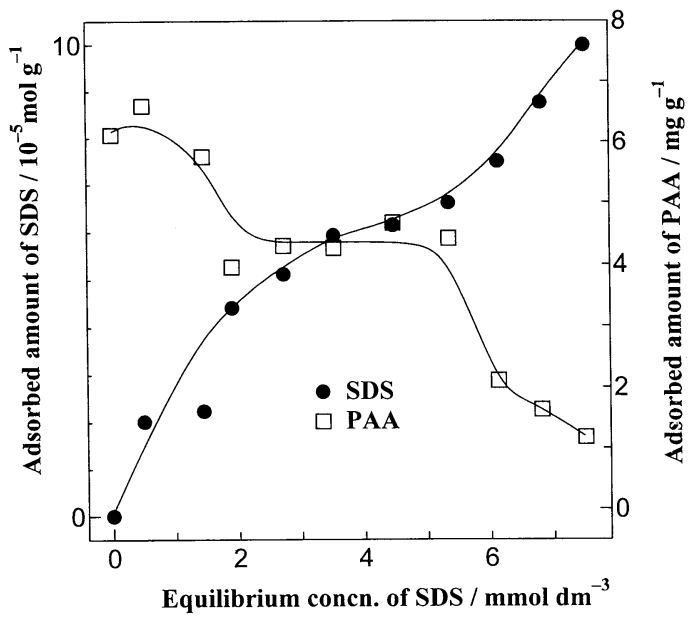

Fig. 2 Simultaneous adsorption of PAA and SDS on alumina at $25^{\circ} \mathrm{C}$ : the initial concentration of PAA is $0.8 \mathrm{~g} \mathrm{dm}^{-3}$.

an initial concentration of PAA was fixed at $0.8 \mathrm{~g} \mathrm{dm}^{-3}$. One can see that the amount of PAA adsorbed decreases with increasing SDS concentration, while the amount of SDS adsorbed increases with the SDS concentration, indicating a competitive adsorption between PAA and SDS.

For the kinetics of adsorption of PAA and SDS on alumina, two initial concentrations of SDS were

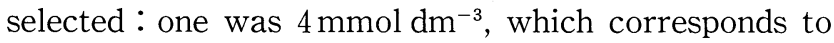
the monolayer of SDS adsorption ${ }^{15)}$, and the other was $10 \mathrm{mmol} \mathrm{dm}^{-3}$, which corresponds to the bilayer of SDS adsorption. The initial concentration of PAA used was $0.8 \mathrm{~g} \mathrm{dm}^{-3}$. Figure 3 shows the adsorption kinetics of PAA and SDS on alumina. The adsorption for three single systems occurred very fast within $500 \mathrm{~s}$ and then increased very gradually with time. Generally, adsorption of polymers takes longer time to reach an equilibrium compared to that of surfactants. However, in this study a clear difference in the adsorption kinetics between PAA and SDS was not observed.

The results for simultaneous adsorption of PAA (initial concentration, $0.8 \mathrm{~g} \mathrm{dm}^{-3}$ ) and SDS (initial concentration, 4 and $10 \mathrm{mmol} \mathrm{dm}^{-3}$ ) are shown in Figs. 4 and 5. In the PAA $\left(0.8 \mathrm{~g} \mathrm{dm}^{-3}\right)-\operatorname{SDS}\left(4 \mathrm{mmol} \mathrm{dm}^{-3}\right)-$ alumina system, the adsorption behavior of PAA with time was very unique; the adsorption was very fast and showed a maximum at around $200 \mathrm{~s}$ and then sharply decreased and became constant above $1000 \mathrm{~s}$. On the other hand, the adsorption of SDS increased sharply within $300 \mathrm{~s}$ and then became constant. Further, the adsorption of SDS in the presence of PAA was greater than that in the absence of PAA as a function of running time, indicating that the adsorption of SDS is enhanced due to less electrostatic repulsion between

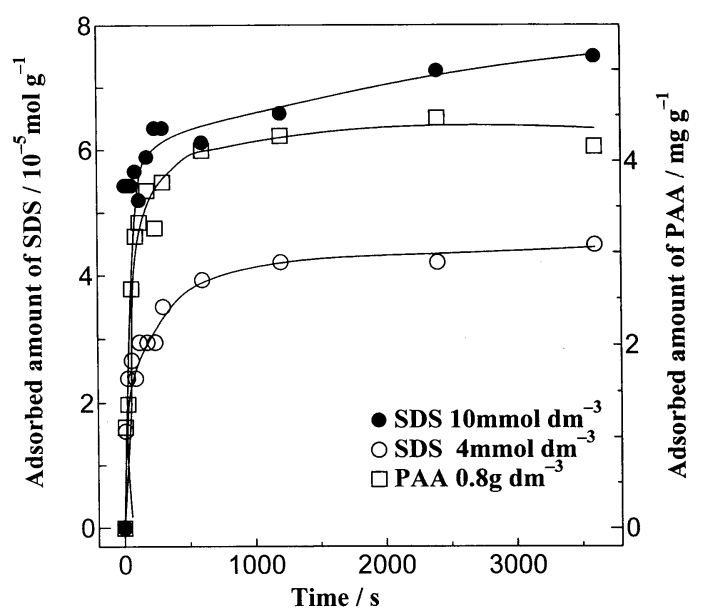

Fig. 3 Adsorption kinetics of SDS and PAA on alumina at $25^{\circ} \mathrm{C}$ : the initial concentration of PAA is $0.8 \mathrm{~g}$ $\mathrm{dm}^{-3}$ and those of SDS are 4 and $10 \mathrm{mmol} \mathrm{dm}^{-3}$, respectively.

SDS molecules adsorbed upon incorporation of PAA. The change in the adsorption of PAA within $700 \mathrm{~s}$ can be interpreted as follows. From the result that the surface tensions of SDS in the presence and in the absence of PAA are not so different the interaction between PAA and SDS can be considered to be very weak in aqueous solution. It is therefore reasonable to consider that at a very early stage both SDS and PAA molecules adsorb on the positively charged sites and hydroxyl groups on the alumina surface. Then, the adsorbed PAA molecules would be replaced by SDS because the interaction between SDS and the surface of alumina is much stronger than that between PAA and the surface of alumina. A more remarkable change in the adsorption kinetics was observed for PAA $(0.8 \mathrm{~g}$ $\left.\mathrm{dm}^{-3}\right)$-SDS $\left(10 \mathrm{mmol} \mathrm{dm}^{-3}\right)$-alumina system, as shown in Fig.5. A marked increase in the adsorption of PAA was also observed at an early stage and then the amount of PAA adsorbed decreased with time, while the adsorption of SDS also increased remarkably at a early stage and then became constant at above $1000 \mathrm{~s}$. Since SDS micelles, both SDS monomer, and PAA are present in the initial solution of $\operatorname{SDS}\left(10 \mathrm{mmol} \mathrm{dm}^{-3}\right)$, SDS and PAA molecules contact with the surface of alumina at an early stage. However, with an increase of the running time the adsorbed PAA molecules are easily replaced by SDS molecules which will adsorb as bilayer.

To understand the kinetics of simultaneous adsorption of PAA and SDS, the adsorption kinetics for the sequential addition of PAA and SDS to alumina was also examined. Figure 6 shows the adsorption kinetics of PAA (initial concentration, $0.8 \mathrm{~g} \mathrm{dm}^{-3}$ ) and SDS (4 mmol $\mathrm{dm}^{-3}$ ): (a) sequential addition of PAA and 


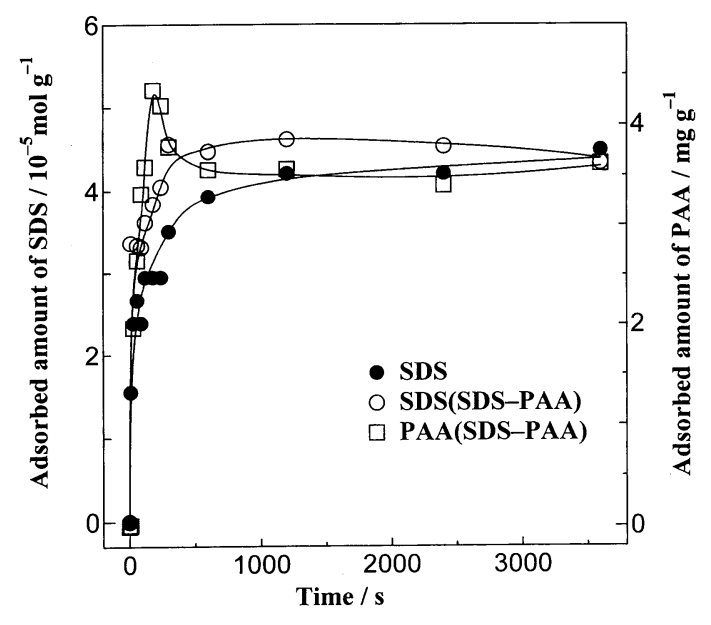

Fig. 4 Adsorption kinetics of SDS and SDS-PAA mixture on alumina at $25^{\circ} \mathrm{C}$ : the initial concentrations of PAA and SDS are $0.8 \mathrm{~g} \mathrm{dm}^{-3}$ and $4 \mathrm{mmol} \mathrm{dm}^{-3}$, respectively.

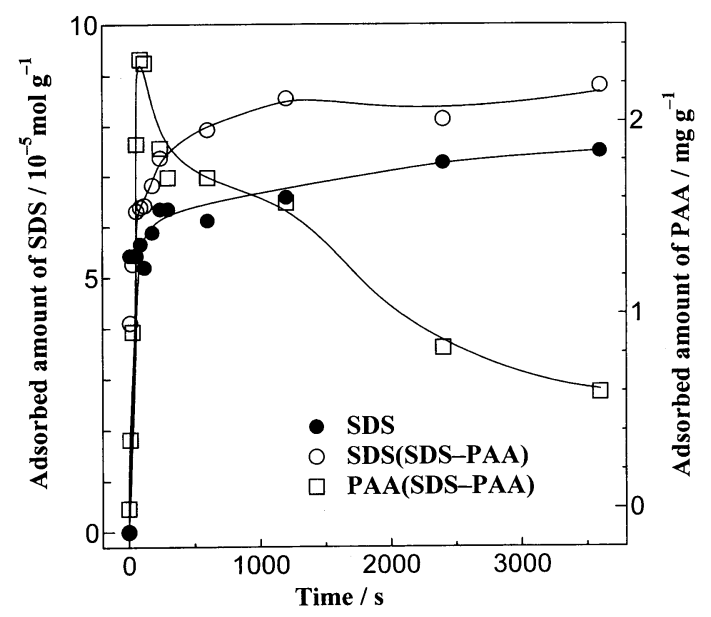

Fig. 5 Adsorption kinetics of SDS and SDS-PAA mixture on alumina at $25^{\circ} \mathrm{C}:$ the initial concentrations of PAA and SDS are $0.8 \mathrm{~g} \mathrm{dm}^{-3}$ and $10 \mathrm{mmol} \mathrm{dm}^{-3}$, respectively.

SDS ; (b) sequential addition of SDS and PAA. It is interesting that in both cases the adsorbed amount of SDS is very similar to each other, while the adsorbed amount of PAA in the case of (a) is much greater than that in the case of (b). In the case of (b), PAA molecules would be adsorbed on the surface of the adsorbed SDS molecules due to hydrophobic interaction between hydrocarbon chains of SDS and PAA. On the other hand, in the case of (a) SDS would be adsorbed on sites on alumina surface which PAA molecules do not occupy. The pattern of (a) is rather similar to that shown in Fig.3. Figure 7 also shows the adsorption kinetics of PAA (initial concentration, $0.8 \mathrm{~g} \mathrm{dm}^{-3}$ ) and SDS $\left(10 \mathrm{mmol} \mathrm{dm}^{-3}\right):$ (a) sequential addition of PAA and SDS; (b) sequential addition of SDS and PAA. One can see that while the adsorbed amounts of SDS in

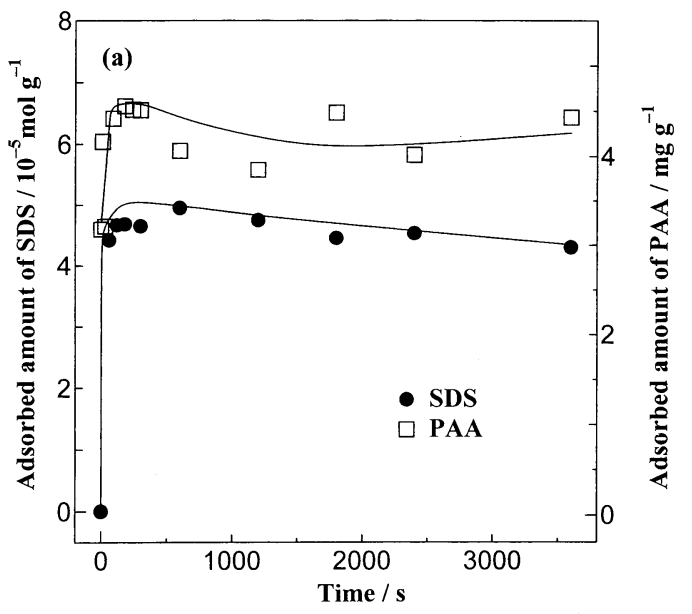

Fig. 6(a)

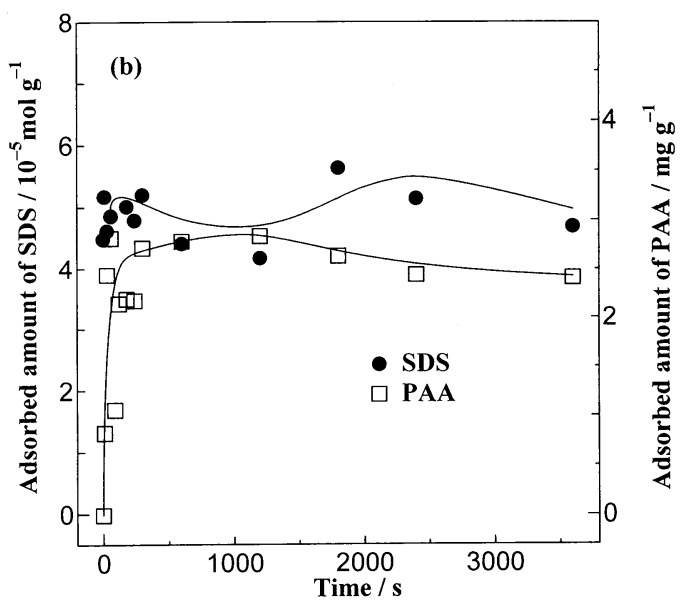

Fig. 6 (b)

Fig. 6 Adsorption kinetics of SDS and PAA on alumina at $25^{\circ} \mathrm{C}$ : (a) sequential addition of PAA and SDS ; (b) sequential addition of SDS and PAA. The initial concentrations of PAA and SDS are 0.8 $\mathrm{g} \mathrm{dm}^{-3}$ and $4 \mathrm{mmol} \mathrm{dm}^{-3}$, respectively.

both cases are not so different, the adsorbed amount of PAA in the case of (a) is gradually decreased with running time, but in the case of (b) the adsorbed amount of PAA is relatively small at above $1000 \mathrm{~s}$. This low adsorption of PAA in the case of (b) is due to the repulsion force between negatively charged PAA molecules and preformed SDS bilayer. The pattern of (b) is also similar to that shown in Fig.4. Accordingly these results indicate that in the kinetics of simultaneous adsorption of PAA and SDS, PAA and SDS adsorb competitively on alumina surface at the low SDS initial concentration, while at the high SDS initial concentration SDS bilayer prevents the adsorption of PAA.

The kinetics of adsorption of PAA and SDS affects the dispersion stability of alumina particles. The change in the dispersion stability of alumina suspensions with running time was investigated using a Tur- 


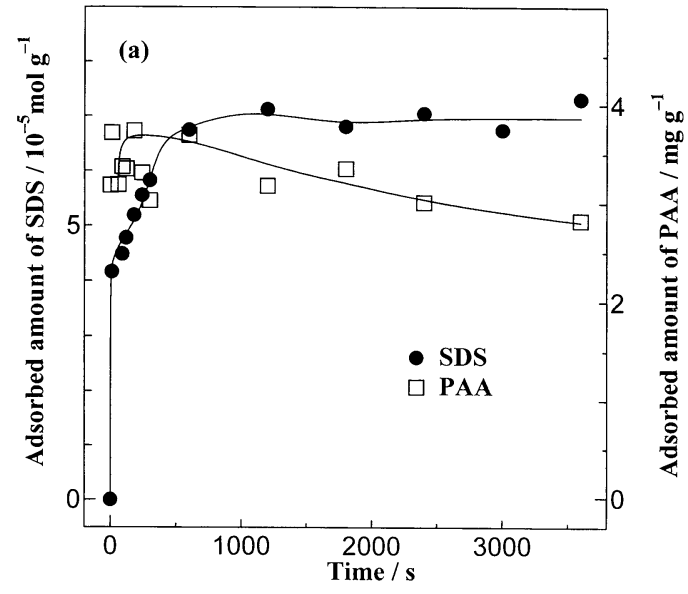

Fig. 7 (a)

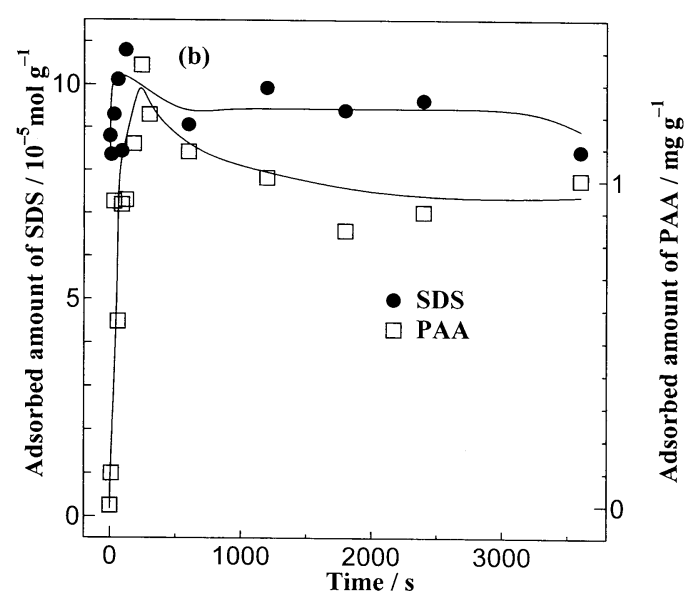

Fig. $7(b)$

Fig. 7 Adsorption kinetics of SDS and PAA on alumina at $25^{\circ} \mathrm{C}$ : (a) sequential addition of PAA and SDS ; (b) sequential addition of SDS and PAA. The initial concentrations of PAA and SDS are 0.8 $\mathrm{g} \mathrm{dm}^{-3}$ and $10 \mathrm{mmol} \mathrm{dm}^{-3}$, respectively.

biscan on line in which the suspension was circulated through the optical sensor using a pump. The optical sensor provides transmitted or backscattered intensity of alumina suspensions. Figure 8 shows the change in backscattering percent of alumina suspensions caused by adsorption of PAA and SDS. It is seen that in the absence of both PAA and SDS the alumina suspensions show a constant backscatttering percent of about $73 \%$, indicating a stable suspension. On the other hand, upon addition of SDS $\left(4.0 \mathrm{mmol} \mathrm{dm}^{-3}\right)$ into the alumina suspension the backscattering percent decreased rapidly until $100 \mathrm{~s}$ and then gradually with the running time. It should be noted here that the backscattering percent is correlated with the particle size: when the backscattering percent decreases, the distance between particles increases, meaning a flocculation of particles. Accordingly the addition of $\operatorname{SDS}\left(4.0 \mathrm{mmol} \mathrm{dm}^{-3}\right)$ makes the alumina particles flocculate and the floccula-

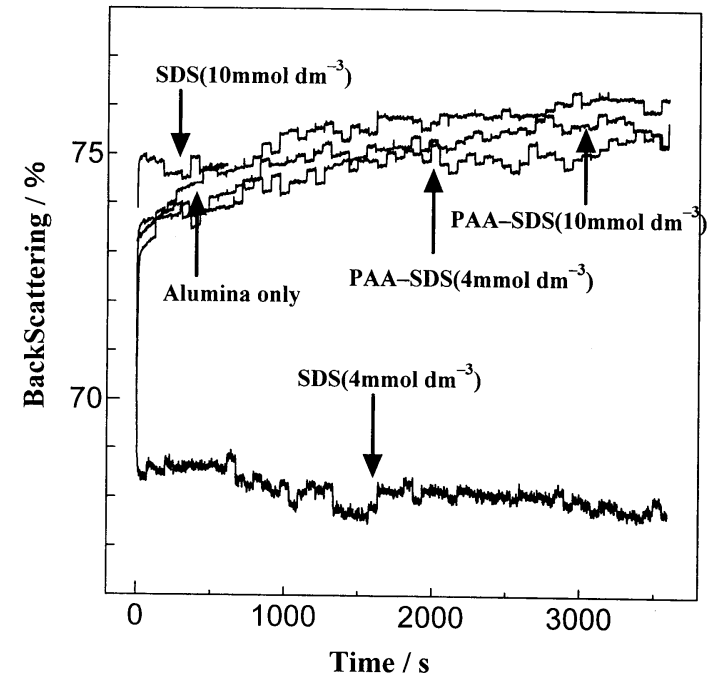

Fig. 8 Change in backscattering percentage of alumina suspensions with time by addition of SDS and SDS -PAA mixtures.

tion process occurs at a very early stage of running time. This flocculation corresponds to the monolayer formation of SDS on alumina particles which exhibits a hydrophobic property. In the case of SDS $(10 \mathrm{mmol}$ $\mathrm{dm}^{-3}$ ) the backscattering percent increased gradually with the running time from $73 \%$ to $76 \%$, suggesting that the dispersion stability increases with the running time due to a formation of SDS bilayer on the alumina surface. It is found from the kinetics of adsorption and dispersion stability that the rate of SDS bilayer formation on the alumina particles is much slower than that of SDS monolayer formation. In the simultaneous adsorption of PAA and SDS, the backscattering percent increased gradually with the running time for both systems with low and high SDS initial concentrations, indicating a good-dispersed system. Two factors responsible for the good dispersion are suggested : one is due to a steric hindrance by PAA adsorbed layer and the other is due to electrostatic repulsion forces by SDS bilayer. In the system of PAA-SDS $\left(4 \mathrm{mmol} \mathrm{dm}^{-3}\right)$, because a good dispersion is obtained in spite of a formation of SDS monolayer the PAA adsorbed layer would be extended to the aqueous phase, resulting in the increase of the repulsion force due to a steric hindrance. An electrostatic repulsion force would also be operated to some extent by dissociated PAA adsorbed on alumina. In the system of PAA-SDS $\left(10 \mathrm{mmol} \mathrm{dm}^{-3}\right)$, the adsorption on alumina is predominantly controlled by SDS where a bilayer of SDS is formed. This adsorption situation is very similar to SDS $\left(10 \mathrm{mmol} \mathrm{dm}^{-3}\right)$ adsorption alone. Accordingly an electrostatic repulsion force induced by SDS bilayer leads to a good dispersion for the PAA-SDS $\left(10 \mathrm{mmol} \mathrm{dm}^{-3}\right)$ system. 


\section{Conclusions}

Adsorption kinetics of PAA and SDS on alumina at $\mathrm{pH} 5.2$ showed that in the adsorption of binary mixtures of PAA and SDS the adsorption of PAA increases remarkably at a very early stage, but decreases rapidly and then becomes constant with the running time, while the adsorption of SDS increases rapidly and then becomes constant. For the both initial concentrations of SDS employed, which correspond to the concentrations for monolayer SDS adsorption and bilayer SDS adsorption, the replacement of adsorbed PAA by adsorption of SDS is much faster at the higher SDS concentration than that at lower one where the adsorbed amount of PAA at lower SDS initial concentration is greater than that at higher SDS initial concentration. In addition, from adsorption kinetics of the sequential addition of PAA and SDS it is also suggested that in the simultaneous adsorption of PAA and SDS, PAA and SDS adsorb competitively on alumina surface at the lower SDS initial concentration, while SDS bilayer formed at very early stage prevents the adsorption of PAA at the higher SDS initial concentration. The backscattering changes in the alumina suspensions caused by addition of PAA/SDS for both initial SDS concentrations are very similar, indicating a high dispersion stability.

\section{Acknowledgments}

We would like to thank Formulaction for the use of a Turbiscan-on-line.

\section{References}

1) K. Esumi, in "Polymer Interfaces and Emulsions", (K. Esumi, Ed.), Chap.12 and references therein. Marcel Dekker, New York, 1999.

2) K. Esumi, M. Iitaka and Y. Koide : J. Colloid Interface Sci., 208, 178 (1998).

3) H. Otsuka and K. Esumi : Langmuir, 10, 45 (1994).

4) H. Otsuka, K. Esumi, T. A. Ring, J-T. Li and K. D. Caldwell : Colloids Surf., 116, 161 (1996).

5) C. Ma and C. Li:J. Colloid Interface Sci., 131, 485 (1989).

6) H. Otsuka, T. A. Ring, J-T. Li, K. D. Caldwell and K. Esumi : J. Phys. Chem. B. 103, 7665 (1999).

7) J. Brink and F. Tiberg: Langmuir, 12, 5042 (1996)

8) D. J. Neivandt, M. L. Gee, C. P. Tripp and M. L. Hair : Langmuir, 13, 2519 (1997).

9) E. S. Pagac, D. C. Prieve and R. D. Tilton : Langmuir, 14, 2333 (1998).

10) A. Krabi and M. A. Cohen Stuart: $M a$ cromolecules, 31, 1285 (1998).

11) F. Joabsson, K. Thuresson and E. Blomberg: Langmuir, 17, 1506 (2001).

12) R. J. Green, T. J. Su, J. R. Lu and J. Penfold:J. Phys. Chem. B. 105, 1594 (2001).

13) K. Esumi, M. Iitaka and K. Torigoe : J. Colloid Interface Sci., 232, 71 (2000).

14) K. F. Tjipangandjara and P. Somasundaran: Colloids Surf., 55, 245 (1991).

15) K. Esumi, K. Sakai and K. Torigoe : J. Colloid Interface Sci., 224, 198 (2000).

アルミナ粒子へのポリアクリル酸とドデシル硫酸ナトリウムの動的吸着の研究

江角邦男*・坂上賢太郎 $*$ 鳥越幹二郎**

*東京理科大学理学部応用化学科・界面科学研究所 東京都新宿区神楽坂 1-3 ( **東京理科大学工学部工業化学科 東京都新宿区神楽坂 1-3 （T 162-8601）

要旨

pH 5.2 でアルミナ粒子へのポリアクリル酸（PAA）とドデシル硫酸ナトリウム (SDS) の動的吸着挙動を吸着量ならびに分 散安定性の時間変化から調べた。PAA とSDSの単独系からの吸着量は短時間で急激に増加し飽和に達した。一方, 単分子層 吸着ならびに二層吸着に対応する $2 つ$ 初期濃度を用いたSDS と PAA の同時吸着において，PAA の吸着量は短時間でいち じるしく増加してから減少し，一定值に達し，またSDSの吸着量は単独の場合と同じ挙動を示した。さらに，アルミナ粒子の 分散安定性も PAA ならびにSDS の吸着時間に対して影響を受けた。アルミナ粒子へのPAA と SDS との動的な吸着挙動の機 構について議論した。 